\title{
7. Opportunities for development journalism in Papua New Guinea
}

\section{ABSTRACI}

The Social Journalism Awards (SJA) is a journalism exchange programme providing Papua New Guinean journalists with opportunities to report on development issues. This article draws on information collected from SJA participants, and analysis of the media content they produced, to gather insights into development journalism in Papua New Guinea. The study found that Papua New Guinean journalists are interested in reporting on development issues but they lack appropriate opportunities to do so. The main issues facing Papua New Guinean journalists include few opportunities to report on issues outside the national capital; few professional development or training opportunities; few opportunities to report on development issues, particularly those affecting the rural poor; conflicts of interest for media owners including the government and foreign corporations with mining interests; and low pay within the industry. The study showed that when given appropriate opportunities, PNG journalists can contribute to development and democracy in meaningful ways. The article concludes that it is important for media indices to go beyond procedural freedoms and to measure substantive freedoms, or opportunities, available to journalists.

Keywords: communication for development, development communication, development journalism, journalism exchange, media development, media training, social journalism, Papua New Guinea

\section{LYNDAL ROWLANDS}

University of Melbourne

VIPUL KHOSLA

Australian Broadcasting Corporation

APUA NEW GUINEA is a culturally and geographically diverse
country with an estimated population of more than 7 million people
across 600 islands, and more than 800 known languages. PNG is also a

96 PACIFIC JOURNALISM REVIEW 20(2) 2014 
relatively young nation state; in 2015 Papua New Guinea will reach 40 years of independence (World Bank, 2014; DFAT, 2013).

Papua New Guinea's recent history has been shaped by human and environmental development challenges. Despite experiencing a natural resources boom Papua New Guinea's economy is increasingly unequal and its governance systems remain fragile. The negative correlation between poor development indicators and natural resource wealth in developing countries has been described as the resource curse (Morris, 2011). Papua New Guinea is one of the lowest ranked countries in the Asia-Pacific region on the Human Development Index (UNDP, 2012) and the only country in the Western Pacific region not on track to meet any of the seven measurable Millennium Development Goals by 2015 (PIF, 2013).

Papua New Guinea is the closest neighbouring country to Australia, however the relationship between the two countries has been characterised by inequality. Papua New Guinea ranks 154 places lower on the United Nations Development Index than its neighbour and former coloniser (UNDP, 2012). Australia's contemporary role in Papua New Guinea includes private mining interests, bilateral aid and the controversial Manus Island Detention Centre for asylum seekers.

\section{Media in Papua New Guinea}

Many Papua New Guinean journalists want to report on development issue; they are conscientious, educated and free in comparison to their neighbours in the Pacific Islands, however there are also serious limitations to their development journalism in practice. These limitations are characterised among PNG journalists by the dichotomy in the intent to serve the community and the practice towards furtherance of individual professional goals. PNG journalists 'are attracted to journalism mostly because they want to communicate knowledge to their community' (Robie, 2004, p. 22) and demonstrate 'sophisticated values in their relationship and role within the community' (Sharp \& Papoutsaki, 2008, p. 84). McManus \& Papoutsaki found that 79 percent of PNG journalism students surveyed were 'interested in working in development communication to help isolated communities'. However, when questioned further, students were more likely to prioritise 'comfortable jobs, good wages and opportunities for career enhancement (over) giving service to the community and living in an isolated place' (McManus and Papoutsaki, 2004, p.10). 
These are not the only challenges facing PNG journalists. While Papua New Guinean journalists are more likely than their Pacific Island neighbours to be tertiary educated, they tend to have relatively little professional experience, in part due to low wages which negatively affect retention rates (Papoutsaki, as cited in Singh \& Prasad, 2012, p. 89). They have also been described as lacking critical and analytical skills, and in-depth knowledge of crucial issues that dominate national development (Sharp \& Papoutsaki, 2008, p. 85).

According to Sharp and Papoutsaki, PNG journalists could be doing a lot more to address Papua New Guinea's many development challenges:

Papua New Guinea has been facing serious development challenges (which) have not been sufficiently covered by the media that follow the Western news values that promote urban-based elites' needs. (Sharp \& Papoutsaki, 2008, p. 87)

Sharp and Papoutsaki add that while there is a need to teach critical and analytical skills, feedback from Papua New Guinean journalism students indicated it may be more culturally appropriate to teach journalists how to employ a more collaborative approach (Sharp \& Papoutsaki, 2008, p. 87). According to David Robie, 'more resources and greater priority also need to be put into development communication and journalism and the development of journalism in remote (areas)' (Robie, 2008, p. 75). Robie argues that this should be done through support for strengthening and enhancing the sustainability of pre-existing media and education institutions, as a more sustainable approach to supporting media development in the region (Robie, 2008, p. 75).

Papua New Guinea's public radio broadcaster, the National Broadcasting Corporation (NBC), is the best placed media platform to reach Papua New Guinea's provincial audiences, the more than half of the adult population who are illiterate or semi-literate, and to cater to PNG's 'strong and diverse oral culture' (Rooney \& Papoutsaki, 2008, p. 112). Known to listeners as 'the voice of the nation', the NBC is one of Papua New Guinea's most far-reaching sources of information and news with 2-3 million daily listeners in rural and urban Papua New Guinea (InterMedia et al, 2012; NBC, 2013). The Citizen Access to Information in Papua New Guinea study found that mobile devices and radios were the two most widely used media in Papua New Guinea in 2011-2012 (InterMedia et al, 2012, p. 10). The survey results also showed that 
57 percent of Papua New Guineans who had used a phone in the last week had used the phone to listen to the radio, compared to only 15 percent who said they had used a mobile to access a website and 13 percent who had accessed social media (InterMedia et al, 2012, p. 51).

Internet access in Papua New Guinea's media landscape currently remains low (relative to much of the world) but its uptake and influence is expanding rapidly (see for example, Cave, 2012; Logan, 2012; World Bank, 2011), enabled in part by mobile data connections. One example includes the popular Papua New Guinean Facebook group Sharptalk which had more than 16,000 members at January 2014. However, radio continues to have an important place in the Papua New Guinean media landscape, particularly in regional areas.

In Papua New Guinea, most 'media organisations are based in the national capital of Port Moresby, a centre that is only connected to the rest of the country by air' (Rooney \& Papoutsaki, 2008, p. 109), although sealinks are important. More than 90 percent of the population live outside of the national capital but flights from Port Moresby to the districts are expensive. Often journalists' travel expenses are sponsored by politicians or businesses who want media coverage of events involving themselves, making journalists 'captive' to their sponsors (Rooney \& Papoutsaki, 2008, p. 109).

The NBC is the only mass media organisation in PNG which is not foreign owned. For example, The Post-Courier is 63 percent owned by Rupert Murdoch's News Corp and The National is owned by Malaysian conglomerate Rimbunan Hijau, a company which runs Papua New Guinea's biggest forestry and timber processing operation, and also has interests in palm oil, retail and property development (Callick, 2013; Rimbunan Hijau (PNG) Group, 2013). Aside from foreign interests, the Papua New Guinean government is also influential; PNG media are heavily reliant on government advertising as a source of revenue (Robie, 2008, p. 61).

Papua New Guinea ranked relatively highly in both the Reporters without Borders 2013 World Press Freedom Index and the 2013 Freedom House Freedom of the Press Rankings. Reporters without Borders rank PNG at 41 out of 179 and Freedom House Freedom rank PNG at 55 out of 197 countries (and territories), which places Papua New Guinea in the 'free' category. ${ }^{1}$

\section{The Social Journalism Awards}

The Social Journalism Awards is a journalist exchange programme which 
helps build the capacity of Papua New Guinean journalists to produce media content about development issues. The programme has two streams. The first stream, called ABC-NBC Social Journalism Awards, includes NBC staff attachments to ABC Australia (see Mikami et. al., 2013). This research focuses on the second stream, the ABC-NBC Social Journalism Awards (SJA), which aims to develop journalists' skills by providing opportunities to work at different provincial radio stations within the PNG National Broadcasting Corporation (NBC) network. Participants, who are employees of the NBC based at different locations, are selected based on their demonstrated interest in reporting on a specific area of development - health, education, gender or governance. During the four-week exchange the journalists produce and air content, gaining skills, knowledge and experience reporting on the topic on their chosen area of interest.

The Social Journalism Awards programme is managed by the Papua New Guinea Media Development Initiative (MDI) and is funded by the Australian government's aid programme. The MDI is a partnership between the PNG National Broadcasting Corporation (NBC) and Australian Broadcasting Corporation International Development (ABCID).

This programme design was informed by results from the 2012 Citizen Access to Information in Papua New Guinea (CAI) survey. Survey results showed that Papua New Guineans believe that NBC radio presenters need opportunities to refresh their skills and improve their presentation style. Nonregular NBC listeners say that 'NBC presenters are of poor quality, sound tired and outdated, and should be replaced with more professional and engaging announcers and presenters' (InterMedia et al, 2012, p. 46) while some regular listeners suggested that NBC could 'be improved by sending new announcers to breathe life into the station' (InterMedia et al, 2012, p. 45). In the survey, many regular listeners also called for more interesting ( 26 percent) and topically diverse programmes (19 percent), and longer programmes ( 23 percent) (InterMedia et al, 2012, p. 48).

The top ten information needs reported by participants in the CAI survey included: news from the province you live in; news from the province you come from; health; and education (InterMedia et al, 2012, 19). These information needs were integrated into the design of the SJA. The survey results showed that media content on health and education tends to be more highly regarded by disadvantaged population groups in Papua New Guinea, including 
Highlanders, those with no formal education and women (InterMedia et al, 2012 , p. 19). The lower educated also valued information on malaria, maternal and child health and HIV and AIDS (InterMedia et al, 2012, p. 19). 'PNG citizens living in the Highlands - the region with the highest illiteracy rate in PNG - also highly value news and information about education, schooling and training' (InterMedia et al, 2012, p. 19). Forty-six percent of regular NBC listeners reported they would like to hear more content on domestic violence.

\section{SJA participants and outputs}

Twenty National Broadcasting Corporation radio journalists completed fourweek attachments as part of the first four rounds of the ABC-NBC Social Journalism Awards between September 2011 and November 2012. Eleven men and nine women participated. The journalists came from 10 different provinces throughout PNG, and were posted to 14 different provinces. In total the programme covered 16 of Papua New Guinea's 22 provinces, (see Table 1).

\section{Table 1: List of home and host radio stations}

\begin{tabular}{|l|l|l|c|c|}
\hline Town/City & \multicolumn{1}{|c|}{ Province } & \multicolumn{1}{c|}{ Region } & Home station & Station posted to \\
\hline Buka & Bougainville & Islands & 12 & 2 \\
\hline- & Central & Papua & 1 & 0 \\
\hline Kundiawa & Chimbu & Highlands & 3 & 0 \\
\hline Kokopo & East New Britain & Islands & 0 & 1 \\
\hline Rabaul & East New Britain & Islands & 1 & 0 \\
\hline Wewak & East Sepik & Momase & 2 & 1 \\
\hline Goroka & Eastern Highlands & Highlands & 0 & 1 \\
\hline Port Moresby & National Capital District & Papua & 3 & 2 \\
\hline Madang & Madang & Momase & 0 & 2 \\
\hline Lorengau & Manus & Islands & 0 & 1 \\
\hline Alotau & Milne Bay & Papua & 4 & 3 \\
\hline Kavieng & New Ireland & Islands & 2 & 2 \\
\hline Popendetta & Northern (Oro) & Papua & 0 & 1 \\
\hline Mendi & Southern Highlands & Highlands & 1 & 1 \\
\hline Vanimo & Sundaun & Momase & 0 & 1 \\
\hline Mt Hagen & Western Highlands & Highlands & 1 & 1 \\
\hline Daru & Western Province & Papua & 0 & 1 \\
\hline
\end{tabular}


During their attachments, the journalists produced and aired a total of 41 hours and 3 minutes of Communication for Development content, including ${ }^{2}$ $18 \mathrm{hr} 9 \mathrm{~min}$ of content on health, $13 \mathrm{hr} 6 \mathrm{~min}$ on education, $13 \mathrm{hr} 58 \mathrm{~min}$ on gender, and $1 \mathrm{hr} 14 \mathrm{~min}$ on governance and related issues. Just over half of the programmes were presented solely in English, with 22.4 percent presented solely in Tok Pisin and 26.5 percent presented in English and Tok Pisin.

\section{Theory: development and democracy}

Media is important as both a means and ends to development and democracy. Media and development theorists agree on the importance of public discussion, facilitated by the media, to both development and democracy (Sen, 1999, p. 281; Habermas, 1989; Jacobson, 2008; Hamelink, 2002, p. 8; Quarry \& Ramirez, 2009; Quebral, 2012, p. 10). As more than just the means to development, inclusive public conversations, facilitated by a conscientious media, have the ability to create a more inclusive, equitable form of development. The importance of communication to development is described by Roberge as follows:
For some, development is simply a matter of imitating the achievements of the so-called developed countries; whereas for others, development is the unfolding of harmony among people living in justice, in conver- sation and in respect of their physical environment. (Roberge, as cited in Quarry \& Ramirez, 2009, p. 17)

Amartya Sen says that 'press freedom and democratic guarantees are necessary for making a high-performing development path secure and stable, rather than fragile' (Sen, 2013, p. 12); he adds that a free press should be considered more than its own reward. Sen provides four 'distinct reasons in favour of encouraging and facilitating uncensored public discussion through the media'. First, a free press supports freedom of speech by providing 'an avenue for citizens to express themselves'. Second, a free press contributes to informed politics and enriches 'public debates on the diagnoses of the problems to be addressed, and on the assessment of (development) policies'. Third, press freedom plays a protective role by 'giving voice to the neglected and the disadvantaged, and thus helping the cause of greater human security'. Fourth, the functioning of a free press and its contribution to open public discussion are important in generating new ideas, including the formation and scrutiny 
of values and 'the emergence of shared public standards, which are central to discussions on social justice' (Sen, 2013, p. 8-9).

In his formative development text Development as Freedom, Sen differentiates between procedural freedoms, 'the processes that allow freedom of actions and decisions', and substantive freedoms, 'the actual opportunities that people have, given their personal and social circumstances' (Sen, 1999, p. 33). Describing the conditions needed for a free press to contribute to development and democracy, Sen explains that such freedom 'can be most effective only when that freedom is utilised by the media fully, rather than in a biased or slanted way', freedom is a permissive condition, and permission is not enough to make a success of the use of the opportunity available (Sen, 2013 , p. 7). Therefore, although procedural media freedoms are important, substantive freedoms, or opportunities, are also needed, and importantly good development communicators are needed to make use of them.

But what constitutes a good development communicator? Quebral says that development communicators must not only be 'knowledgeable in communication skills but also in the subject matter to be communicated'. More importantly the development communicator must have 'a sense of commitment and individual responsibility to development' (Quebral, 2012, p. 18).

All of these factors, as well as the complexity of political relationships in PNG mean that a conscientious media is particularly important. According to Devi and Chand the "risk of the "free press" cutting the wrong way as far as development and democracy are concerned (is) much higher in smaller island nations like those in the Pacific' (Devi \& Chand, 2008, p. 265). Devi and Chand argue that:

The real issue for the Third World, and more so for the Pacific Island nations, is not so much whether it has a 'free press', or the extent of state, business or special interest control over the press, but, first a conscientious press, and second, a well-trained journalist. (Devi \& Chand, 2008, p. 265, emphasis added)

Devi and Chand go further to say that ideally journalists should have critical and analytical skills and an understanding of economics and social sciences to understand the structural causes of inequality (Devi \& Chand, 2008). Robie (2014) argues that deliberative journalism is particularly important and relevant to the Pacific (p. 321). He says that this requires journalists to 
'FAILED' STATES AND THE ENVIRONMENT

report the news as issues rather than events and to engage in analysis of these issues $(2014$, p. 326).

\section{Methodology}

This research project aimed to provide insights into Papua New Guinean journalists and their relationship to development communication. Questions which the research aimed to answer include: 'Are Papua New Guinean journalists interested in reporting on development issues?' 'What factors prevent Papua New Guinean journalists from reporting on development issues?'; and 'If provided with appropriate support, what kind of journalism about development issues do Papua New Guinean journalists produce?'.

A mixed-methods approach was used to evaluate the Social Journalism Awards programme, including journalists' qualitative self-evaluations and media content analysis. The research was administered by Papua New Guinean researchers in Port Moresby and supported by ABC International Development staff in Australia. ${ }^{3}$

This article draws on analysis of qualitative data collected from participants in the Social Journalism Awards. Participants in the SJA submitted a written report, to the Media Development Initiative. Media Development Initiative staff also conducted follow-up interviews with the journalists by phone, between 3 and 14 months after the journalists had completed their attachments. These phone interviews were semi-structured and were used to ensure consistent data collection from all SJA participants. Journalists were asked to reflect on what they had learnt through the Social Journalism Award and their attitudes to development communication. All interview data was qualitatively analysed to identify themes using a coding frame.

For the media content analysis, 49 of the 276 radio programmes produced during the exchanges were systematically selected and analysed using a code-frame consisting of 24 questions. The selection of the radio outputs for coding was based on the average length of each of the radio outputs. In order to select the most representative radio segment for each of the participants, the average length of output produced was determined and the radio pieces closest to the average length were selected. This was essential as the radio outputs were of varying lengths and a significant difference in the length of the radio segments would make any contrasts and comparison challenging and manifest in inconsistent results. Questions covered topics including number 
and type of sources used in a story, language prevalence, topics and sub-topics covered and genre of the radio segment. All segments were coded consistently across all questions.

Although content analysis and participant self-evaluation are suggested as appropriate means for evaluating journalism training programs (BBC World Service Trust, 2008, p. 1) there are limitations to these two methods. Jacobson (2008) says that media-development evaluators should use audience research to assess the level of public engagement with content produced. Audience research was beyond the scope of this study, however this report draws on information from the Citizen Access to Information in Papua New Guinea survey (2012).

The content analysis provides insights into overall outputs produced as part of SJA. The selection of content was systematic and therefore does not provide for a random sample. The findings from the content analysis are applicable for the sample of content selected and coded and not for the overall outputs produced as part of SJA. While the sample may not be completely representative of the overall output, it provides insights into sources, language, topics and sub-topics covered as part of SJA.

When researching international development programs, international researchers should be reflexive and mindful that 'development generally positions the poor and marginalised as listeners rather than speakers' (Lennie \& Tacchi, 2011, p. ix). Evaluators of development programmes should also consider that good evaluation of development programs should be about 'understanding and improving' rather than 'measuring' and 'proving' (Byrne, 2008, p. 9 as cited in Lennie and Tacchi, 2011).

\section{Findings}

\section{Conscientious journalism}

Feedback from participants in the first four rounds of the SJA suggests that NBC staff are interested in reporting on development issues; some participants also expressed an interest in specialising in their chosen topic areas. Ten of 17 respondents expressed a strong commitment to producing communication for development content in the follow-up interview. One participant reported that she had become known as a specialist in safe motherhood and health after participating in the SJA: 


\section{‘FAILED’ STATES AND THE ENVIRONMENT}

I covered safe motherhood on my attachment with NBC New Ireland and coming back to my provincial station out here I've built on that and I've done more packages every week on safe motherhood. My attachment has also made me to go deep into this topic of safe motherhood. Now I have this personal relationship with the workers from the Health Department. When I am on the street people will just call me, come here, we have things to share, so I am happy about going on this attachment and coming back to New Ireland province and doing all this coverage on health issues.

Other participants reported that the SJA had increased its interest in reporting on development issues:

Yes, the attachment has immensely helped me professionally. It has made me more aware of issues which I have thought were just another normal or day to day occurrence. It has really opened up my mind to appreciate these issues and I can say that with this new found understanding I can be able to report on issues with a new dimension. My approach will definitely change.

[The SJA] really broadened my mind and made me understand that there is more to be covered in health issues, not on a broad scale, but there are specific issues that we need to really tackle and talk about, break some cultural barriers to talk about these issues.

Two thirds of respondents ( 10 of $n=15$ ) saw content about development issues as a priority or important issue worth spending more time on. Participants who demonstrated a strong continuing interest in development content were also likely to express commitment to their chosen topic area.

Two participants thought that development content should be balanced with other programming priorities, and another two reported they were unable to report on development issues as much as they wished due to external factors.

I'm basically the only person in my newsroom so I cover all sorts of issues and yes, there have been a couple that have popped up for gender and education which I have used for news purposes.

$[\mathrm{O}]$ nly on occasions where these issues are highlighted or they come about maybe in a more public manner where it needs us to cover it, much of the time prominence is given to other areas of news stories rather than a specific issue like gender based violence. 
Only one journalist showed little interest in producing development related content, both before, and after the attachment.

Opportunities and challenges for media in $P N G$

All of the journalists who took part in the participant evaluation (17 of 17) reported that the attachment helped them professionally, with 12 of the 17 emphasising that the attachment had helped them 'a lot', 'immensely' or 'so much'. In the follow-up interviews 18 participants listed the professional benefits of the programme as follows: broadcasting skills (10), networking / relationship building opportunities (8), increased knowledge/understanding of chosen topic (7) and increased confidence (4).

It was also acknowledged that $\mathrm{NBC}$ had few opportunities for professional development with one participant reporting that the SJA was one of the only opportunities for professional development they had had since joining the NBC in 1999:

To tell you the truth I signed my recruitment in 1999 ... the last 10 or 11 years I was not properly trained so with MDI I think it is very good. It has helped me out with interviews, story packaging and more.

Follow-up interviews, with 13 of the 20 participants, demonstrated that most of the journalists had passed on skills or knowledge to their colleagues after returning to their home station. Eleven journalists ( $\mathrm{n}=13$ journalists) reported that they had shared skills learnt during their attachments with their colleagues after returning to their home station. One journalist from NBC Milne Bay (Alotau), reported that she was able to share the increased confidence she gained through the SJA program with her colleagues at her home station:

Yes, I passed it on to some of my colleagues here, maybe just encouraging them to do a lot of stories, a lot of interviews and do a lot of live crosses to national radio where you can build your confidence in being a broadcaster.

One of the factors which influenced whether journalists could pass on skills to their colleagues was whether their home station had editorial meetings.

We've started our editorials late last year when I returned. We had a meeting and we decided to do something about (having editorials). We've found out that when we have editorials, we had buckets full of ideas which we can expand on. 


\section{‘FAILED’ STATES AND THE ENVIRONMENT}

Access to remote areas was a key limitation raised by some participants. Some participants expressed a particular interest in reporting on remote areas, but they acknowledged that they did not have the resources to do so:

We cannot get stories of significant events or information from the remote islands of Catarets, Motlock or Nissan to be exposed through NBC Bougainville because of remoteness. Transportation funds need to be available because funding for provincial radio stations is limited.

\section{Public discussion through the media}

The findings demonstrate that the SJA contribute to each of Sen's four reasons for public discussion through the media, as follows.

\section{(1) Media as an avenue for citizens to express themselves}

Analysis of the overall contents of the radio programs showed a wide range of participants discussing development related issues. Just over half (53 percent) of the radio segments analysed were interview /discussion type programmes. Seventy-three spokespersons were represented across 49 segments

Table 2: Spokesperson representation
\begin{tabular}{|l|c|c|c|}
\hline Spokesperson representation & Female & Male & Total \\
\hline Academia & 5 & 4 & 9 \\
\hline Church group/leader & 0 & 4 & 4 \\
\hline Citizen & 4 & 2 & 6 \\
\hline $\begin{array}{l}\text { Donor, development partner,government, } \\
\text { aid programme, or UN agency }\end{array}$ & 1 & 1 & 2 \\
\hline Educational institution & 3 & 3 & 6 \\
\hline Health care professional/organisation & 11 & 8 & 19 \\
\hline International NGO & 1 & 0 & 1 \\
\hline Media professional & 1 & 1 & 2 \\
\hline National government or representative & 0 & 1 & 1 \\
\hline National or local NGO/community based organisation & 3 & 3 & 6 \\
\hline Other/not specified & 4 & 2 & 6 \\
\hline Professional association/group & 1 & 0 & 1 \\
\hline Provincial or local government representative & 5 & 4 & 9 \\
\hline Student & 0 & 1 & 1 \\
\hline Total & 39 & 34 & 73 \\
\hline
\end{tabular}

108 PACIFIC JOURNALISM REVIEW 20(2) 2014 
analysed, meaning that segments had one or two spokespersons on average. The spokespersons came from a range of backgrounds, also influenced by the segment topics, including health care professionals (19), academics (9), provincial government representatives (8), and representatives from schools and other educational institutions (6). Local NGOs (6) were more represented than international NGOs (1). Six of the spokespersons were citizens with no other affiliations. In total 39 women were interviewed and 34 men.

\section{(2) Media as a forum for public debate about development policy}

The SJA helped create debate about a number of contemporary issues affecting Papua New Guineans. Selected radio programme titles from the SJA included: 'Should 22 seats be reserved for women in Parliament?', 'Mobile clinics - a boost for rural health services', 'How effective is the HIV and AIDS response locally and nationally?', 'Elementary Education in local language', 'Are medical supplies reaching rural areas?' and 'Should Sex Education be introduced in schools?'. Of 49 segments analysed, 11 had a sub-theme or combined sub-theme of Education Policy/Funding.

Table 3: Story sub-themes
\begin{tabular}{|l|c|}
\hline Sub-theme & Count \\
\hline Education/policy funding & 9 \\
\hline Family planning & 1 \\
\hline Family planning, gender-based violence, youth and HIV/AIDS, malaria, STIs & 1 \\
\hline Gender-based violence & 8 \\
\hline Gender-based violence and HIV/AIDS, malaria, STIs and other diseases & 1 \\
\hline Gender-based violence and ICTs & 1 \\
\hline Gender equality in education & 4 \\
\hline General health information & 5 \\
\hline General health information and education policy/funding & 1 \\
\hline HIVIAIDS, malaria, STIs and other diseases & 3 \\
\hline HIVIAIDS, malaria, STIs and other diseases and education policy/funding & 1 \\
\hline HIVIAIDS, malaria, STIs and other diseases and ICTs & 1 \\
\hline Maternal and child health & 9 \\
\hline Maternal and child health, family planning and HIV/AIDS, malaria, STIs & 1 \\
\hline Women in government & 3 \\
\hline Total & 49 \\
\hline
\end{tabular}

PACIFIC JOURNALISM REVIEW 20 (2) 2014109 
(3) Media giving voice to the neglected and the disadvantaged

Participants in the SJA were posted to 14 of PNG's 22 provinces. The participants each received professional handheld audio recorders which meant they were able to conduct interviews outside the studio, including in the streets. Some participants showed an increased interest in covering remote areas following their attachments, for example a journalist from NBC Milne Bay (posted to NBC New Ireland) said that in future she hoped to:

Stay in a remote village and cover safe motherhood there. Study the challenges they face: 'seeing is believing".

The programme also helped give voice to the neglected and disadvantaged by covering issues which can cause neglect and disadvantage. Programmes included interviews with victims and survivors of gender based violence; one programme was titled: 'From an Islanders' Perspective-Gender Based Violence'. As one participant in the SJA explained:

(Violence against Women) is a big issue back in the province, so we try as much as we can to address the issue; we do awareness during our presentation duties, we do even go out and get information from groups who advocate on these issues.

(4) Media and values central to social justice

Participants in the SJA produced content which encouraged public conversations about cultural and social values affecting development issues including gender based violence, HIV and AIDS stigma, attitudes to maternal health and education and professional opportunities for women. In total 43 programmes of the 276 programs produced were about gender based violence, including three $30 \mathrm{~min}$ documentaries. Interviewees in these segments provide examples of how these programs tackled the values which influence gender based violence:

Violence is about the choice we make and every one of us has a choice, we can choose not to be violent or we can choose to be violent. In my view alcohol and drugs should not be an excuse for violence, every person is responsible for the actions they take.

In another interview about education for girls, the interviewee explained:

A family that places too much emphasis on educating only the boys surprises itself when in the long run it is the girls that end up supporting the

110 PACIFIC JOURNALISM REVIEW 20(2) 2014 
family. Even if the boys may have university degrees, they still might not find jobs whereas the girls, who have been denied this, come right back and actually support the whole family. In that sense I would say that we are waking up fast.

Other programmes, which covered values-based questions included programmes called: 'Gender equality - is it a foreign idea, and what is its effect on PNG culture?', 'Churches point of view on gender-based violence', 'HIV and AIDS-related stigma and discrimination, how rife is it in East New Britain Province?' 'Why did women not fare well in 2007 elections?' and 'Women at work-profile of a female civil engineer'.

\section{Discussion}

The results of this study show that, given the right opportunities PNG journalists can produce development journalism which contributes to development and democracy. Some of the aspects of the SJA which make it an appropriate opportunity include: combining professional development with an opportunity to travel to other parts of PNG; combining professional development with a focus on development issues; and encouraging participants to focus on a specific topic area, enabling them to build their knowledge and confidence reporting on a particular development issue. The SJA responded to feedback from the Citizen Access to Information Survey, including the audience's information needs and their opinions of NBC journalists' professionalism. Many of the participants in the SJA expressed commitment and passion for their chosen topic areas. Some participants welcomed the opportunity to spend more time reporting on something they already cared about while others said that having the opportunity to report on a particular development issue helped to 'open their eyes' to the importance of this issue.

This study found that the content produced by SJA participants contributed to all four of Amartya Sen's reasons for a free press. Firstly, content produced through the Social Journalism Awards shows that Papua New Guinean journalists can effectively incorporate a broad range of citizens' voices into their programming. Targeted support provided by the SJA programme encouraged journalists to provide an avenue for Papua New Guineans to cover the issues which mattered to them. Although Papua New Guinean journalists have been criticised for being too focused on urban based elites and Western news values, content produced by the journalists featured a diverse range of Papua 
New Guineans, many of whom were ordinary citizens. Secondly, the results showed that by specialising in a specific area, journalists are able to build their confidence and knowledge of relevant development issues, increasing their confidence to contribute to public debate and policy level discussions in meaningful ways. Thirdly, the Social Journalism Awards provided opportunities for journalists to go beyond the National Capital District to different provinces to interview a wide range of people outside the so-called urban elites. The programme is also helping to provide a voice for the neglected and disadvantaged by covering issues like gender-based violence, HIV and AIDS, and maternal health. Fourthly and finally, participants in the SJA also showed that they were able to contribute to the formation and scrutiny of values which are central to discussions on social justice. This was particularly evident in the area of gender based violence which was the focus of 43 programmes produced. Gender-based violence is a critical problem in Papua New Guinea and globally. In 2013, the World Health Organisation (WHO) described violence against women as a 'global health problem of epidemic proportions' (WHO, 2013).

As highlighted in the findings, development journalism in PNG is not without challenges. Journalists and media particularly in remote provinces are severely constrained in their operations due to limited resources: human, technological and infrastructural. This has a direct impact on the limited capacity of the media to cover stories in remote areas. Within this context, they also have to make choices of stories following western news values or coverage of development issues. Development issues may be given coverage when they relate to topical news but may very quickly be abandoned as they lose their 'newsworthiness'. Lack of training and development on the job also exacerbates this challenge as journalists struggle to hone their critical and analytical skills. While SJA has supported NBC journalists to move in the direction of development journalism, the institutional constraints around resourcing and infrastructure will continue to pose significant challenges in enabling NBC to play its role as the voice of the nation and setting their future strategy for supporting this approach to journalism.

The Paris and Accra Agendas for aid both emphasise the importance of developing countries setting their own strategies for development and having 'more say over their development processes through wider participation in development policy formulation' (OECD, 2014). However in order for govern- 
ments to create development policy which is appropriate it is important that citizens are able to contribute to policy debates in an informed way. The media play an important role in ensuring government accountability, in both developed and developing countries. While the policy level impact of SJA is hard to determine at this stage, the journalists have helped to facilitate a range of discussions on policy issues, thus providing opportunities for citizens to contribute to policy debates.

Papua New Guinea's relatively high ranking in press freedom indices belies the fragility of Papua New Guinea's state. Although Papua New Guinean journalists have procedural freedoms they still need substantive freedoms, or opportunities, including professional development and independent travel. The pressures on journalists can often also be very subtle. Negative responses or punitive action in response to media statements or coverage are described by Hermann and Chomsky as 'flak', one of the five filters of the Propaganda Model. Even the possibility of flak, which is designed to discourage deviance from the official line, can cause journalists to self-censor (Herman \& Chomsky, 1988). Another filter is media ownership. As the only major news organisation in PNG which is not foreign-owned the NBC has an important role to play to ensure that its journalists can operate in a free and fair environment and contribute to Papua New Guinea's development.

This evaluation of the SJA did not include audience research. Further research is needed in this area to assess the impact of the SJA or similar journalism professional development programs on audiences. Audience level research would help provide insight into how far citizens feel empowered in the process of voice, debate and development and their perceptions of the media and how it represents their issues and voices.

The SJA is based on a sustainable model with a focus on building the capacity of PNG journalists through PNG's main national media organisation, the NBC. The SJA program is currently coordinated by the Media Development Initiative (MDI) with funding from the Australian government. While the MDI currently plays an important role, there is a need to develop a transition plan to ensure NBC can sustainably manage training and development activities for NBC staff in the future. The transition would need careful planning and execution to ensure the experience and benefits from SJA and other similar activities continue. 


\section{Conclusion}

The Social Journalism Awards have demonstrated that Papua New Guinean journalists can contribute to development and democracy. Results from this research provide insight into the specific barriers which can prevent them from doing so as well as the specific opportunities which remove these barriers. The main issues facing Papua New Guinean journalists include few opportunities to report on issues outside the national capital; few professional development or training opportunities; few opportunities to report on development issues, particularly those affecting the rural poor; conflicts of interest for media owners including the government and foreign corporations with mining interests; and low pay within the industry which negatively affects retention. The Social Journalism Awards model effectively targets a number of key issues by combining professional development, with exchange opportunities and a focus on development content. Feedback from NBC listeners that NBC presenters need to be more 'professional and engaging' correlates with the journalists' own assessment that they have had limited opportunities for professional development working at the NBC. Although Papua New Guinean journalists are well educated, they need more professional development opportunities. An exchange programme can provide this while also meeting the need for journalists to travel more in order to cover the more than 90 percent of Papua New Guineans who live outside the national capital.

\section{Notes}

1. Reporters Without Borders rank countries according to their levels of pluralism, media independence, environment and self-censorship, legislative framework, transparency, infrastructure and violence against journalists (Reporters Without Borders, 2013). Freedom House rank countries in three categories, legal, political and economic environment (Freedom House, 2013).

2. Some content covered more than one issue e.g. gender and governance. 3. Media Development Initiative, Port Moresby, PNG: Junior Kaulo and Isabel Popal. University of Melbourne, Melbourne, Australia: Lyndal Rowlands. ABC, Melbourne, Australia: Sam Freeman.

\section{References}

BBC World Service Trust. (2008). Using content analysis to measure the influence of media development interventions: Elections training for journalists in Yemen. 
Callick, R. (2013, October 28). PNG moves to restrict foreigners owning shares. The Australian. Retrieved on January 13, 2014, from: www.theaustralian.com. au/business/economics/png-moves-to-restrict-foreigners-owning-shares/storye6frg926-1226747854031.

Cave, D. (2012). Digital islands: How the Pacific's ICT revolution is transforming the region. November 21. Lowy Institute for International Policy. www.lowyinstitute.org

Department of Foreign Affairs and Trade (DFAT). (2013). Papua New Guinea Country Brief. Retrieved on January 13, 2014, from: www.dfat.gov.au/geo/png/png_brief. html

Devi, P., \& Chand, G. (2008). Development journalism: Potential and prospects. In S. Singh \& B. Prasad (Eds.). Media \& development: issues and challenges in the Pacific Islands. Suva: University of the South Pacific; and Auckland: Pacific Media Centre.

Freedom House. (2013). Freedom of the Press Index. Retrieved on January 13, 2014, from www.freedomhouse.org/report/freedom-press/freedom-press-2013.

Habermas, J. (1989). The structural transformation of the public sphere. Cambridge, Mass.: MIT Press.

Herman, E., \& Chomsky, N. (1988). Manufacturing consent: the political economy of the mass media. New York Pantheon Books.

InterMedia, NBC, ABC International Development and AusAID. (2012). Citizen access to information in Papua New Guinea: Citizen survey, June 2012.

Jacobson, T. (2008). Defining and evaluating media development. Retrieved on January 13, 2014, from http://blogs.worldbank.org/publicsphere/defining-andevaluating-media-development.

Lennie, J. \& Tacchi, J. (2011). United Nations Inter-Agency Resource Pack on Research, Monitoring and Evaluation in Communication for Development. Retrieved on January 13, 2014, from: www.cci.edu.au/sites/default/files/ccook/ RME_C4D_Feb2011.pdf

Logan, $\overline{\mathrm{S}}$. (2012). Rausim! Digital politics in Papua New Guinea. SSGM Discussion Paper 2012/9. State, society and governance in Melanesia. Australian National University.

Mikami, A., Khosla, V., Popal, I., \& Freeman, S. (2013). Capturing stories of change: Evaluating media practices of Papua New Guinean journalists during and after media attachment in Australia. Journal of Applied Journalism \& Media Studies, 2(1), 99-118.

Morris, Matthew. (2011). How can PNG fight the resource curse? Development Policy Blog. Retrieved on January 13, 2014, from http://devpolicy.org/how-canpng-fight-the-resource-curse/

National Broadcasting Corporation. (2013). About Us - www.nbc.com.pg/aboutus.htm Organisation for Economic Cooperation and Development (OECD). (2014). Paris Declaration and Accra Agenda for Action. Retrieved on January 13, 2014, from: www.oecd.org/dac/effectiveness/parisdeclarationandaccraagendaforaction.htm.

PACIFIC JOURNALISM REVIEW 20 (2) 2014115 


\section{'FAILED’ STATES AND THE ENVIRONMENT}

Quarry, Wendy \& Ramirez, Ricardo. (2009). Communication for another development: listening before telling. London and New York: Zed Books.

Reporters without Borders. (2013). Press Freedom Index. Retrieved on January 13, 2014, from: http://en.rsf.org/press-freedom-index-2013,1054.html.

Rimbunan Hijau (PNG) Group. (2013). About. Retrieved on January 13, 2014, from: www.rhpng.com.pg/.

Robie, D. (2004). Pacific newsroom profiles: media literacy and education in Fiji, Papua New Guinea'. Paper to Journalism Education Association (JEA), Media Literacy in the Pacific and Asia conference, Suva, Fiji, 5-9 December 2004.

Robie, D. (2008). Changing paradigms in media education aid in the Pacific. In U. Harris and E. Papoutsaki (Eds.), South Pacific islands communication: regional perspectives, local issues (pp. 59-81). Singapore, Auckland, Fiji: NUS, PMC and USP.

Robie, David. (2014). Don’t Spoil My Beautiful Face: Media, Mayhem and Human Rights in the Pacific. Auckland, NZ: Little Island Press.

Rooney, D \& Papoutsaki, E. (2008). Addressing the information needs of a developing nation: a case study of Papua New Guinea. In Banerjee, I \& Madanmohan, R. (Eds.), Media and development in Asia: Regional perspectives. Asian Media Information and Community Centre.

Sen, Amartya. (1999). Development as freedom. Oxford: Oxford University Press.

Sen, Amartya. (2013). Press freedom: what is it good for? Index on Censorship, 42(6), 6-15.

Sharp, S \& E. Papoutsaki. (2008). Two models for Pacific Islands journalism education. In E. Papoutsaki \& U. Harris (Eds.) South Pacific Islands communication. (p. 82-101). Singapore, Auckland, Fiji: NUS, PMC and USP.

Singh, S. \& Prasad, B. (2012). Investigative journalism: Challenges, perils, rewards in seven Pacific Island countries. Pacific Journalism Review, 18(1), 83-104.

UNDP (United Nations Development Programme). (2012). International Human Development Indicators. Retrieved on January 13, 2014, from: http://hdr.undp. org/en/statistics/

PIF (Pacific Islands Forum Secretariat). (2013). Pacific Regional MDGs Tracking Report. Retrieved on January 13, 2014, from: www.forumsec.org/resources/uploads/ attachments/documents/2013_Pac_Regional_MDGs_Tracking_Report_FINAL.pdf

World Bank. (2011). Internet users (per 100 people). Retrieved on January 13, 2014, from http://data.worldbank.org/indicator/IT.NET.USER.P2/countries/1W?display=default

World Bank. (2014). Papua New Guinea. Retrieved on January 13, 2014, from: www. worldbank.org/en/country/png

World Health Organization. (2013, June 20). Violence against women: a 'global health problem of epidemic proportions'. Retrieved on January 13, 2014, from: www.who.int/mediacentre/news/releases/2013/violence_against_women_20130620/en/index.html?utm_source=buffer\&utm_campaign=Buffer\&utm content=buffer56f63\&utm_medium=twitter. 
'FAILED’ STATES AND THE ENVIRONMENT

Lyndal Rowlands is a Master of Global Media Communication student at the University of Melbourne. She is currently a freelance writer based in New York and has previously worked in the development sector supporting programmes across Africa, Asia, the Pacific.

Rowlands.lyndal@gmail.com

Vipul Khosla is manager of research for ABC International Development. Previously, Vipul worked with BBC World Service Trust in London, where he managed a research project funded by the United Nations in Mozambique, Vietnam and Peru. He has supported and managed international research projects in more than 20 different countries in Africa, Asia and the Pacific. He has a Master of Science in Media and Communications from London School of Economics.

Khosla.vipul@abc.net.au

The authors wish to dedicate this article to Media Development Initiative researcher Isabel Popal who sadly died unexpectedly in September 2014. Isabel was an outstanding media development researcher and made a significant contribution to the evaluation of the Social Journalism Awards. She will be greatly missed by her family, friends and colleagues.

The authors wish to also acknowledge Isabel Popal and Junior Kaulo MDI), and Sam Freeman (ABC) for research for this article; and Dr David Nolan (University of Melbourne) for feedback on an earlier draft. 